Marta Grzechnik

University of Gdańsk

\title{
Background Characters? The Nordic Region and European Colonialism
}

This article presents an overview of the literature regarding colonialism in the Nordic countries. Although the Nordic region is not commonly associated with colonialism, a critical look at its direct and indirect involvement in the process of European expansion has recently been developed in scholarship on the region. Direct involvement refers to the control of overseas territories (e.g. in India, modern day Ghana, and the Caribbean) and active participation in the networks of trade (including slave trade), shipping, missionary activity, etc. Indirect involvement, or colonial complicity, refers to the idea that Nordic societies produced and reproduced systems of knowledge that underpinned the colonial system and the global racial hierarchies.

Key words: Scandinavia, Nordic region, colonialism, post-colonialism, colonial complicity

\section{Introduction}

It was only months and months afterwards, when I made the attempt to recover what was left of the body, that I heard the original quarrel arose from a misunderstanding about some hens. Yes, two black hens. Fresleven - that was the fellow's name, a Dane - thought himself wronged somehow in the bargain, so he went ashore and started to hammer the chief of the village with a stick. Oh, it didn't surprise me in the least to hear this, and at the same time to be told that Fresleven was the gentlest, quietest creature that ever walked on two legs. No doubt he was; but he had been a couple of years already out there engaged in the noble cause, you know, and he probably felt the need at least of asserting his self-respect in some way (Conrad 2010: 23).

The decades around the turn of the twentieth century were a period of intensive European expansion and the reinforcement of European control over extraEuropean territories. During a conference in Berlin in 1884-1885, European powers debated the division of their spheres of interest in Africa (more precisely the Congo and Niger territories), as well as questions of trade and maritime policy in that part of the world. Interestingly, among the participants were not only states 
that possessed colonies in Africa, but also, among others, the two Nordic states, Denmark and Sweden-Norway.

The idea of Nordic colonialism can seem surprising to many. In the process of European colonial expansion, the Nordic countries remained in the background. However, background characters in any story can be instrumental in setting events in motion - just like the character of the Dane Fresleven, mentioned only in passing by Charles Marlow, the narrator and protagonist of Heart of Darkness, Joseph Conrad's novella from 1899, but whose rash actions set the stage for Marlow's journey to Africa. In Berlin, these Nordic background characters in the story of European colonialism were invited to the negotiation table as partners - a privilege that was not extended to the African countries themselves (Mommsen 1988: vi).

In recent years, the Nordic contribution to European colonialism - however minor it might appear in comparison to that of the traditional colonial powers like Great Britain and France - has emerged as the topic of a growing body of research. It is the result of several research projects and networks, many of which do not limit themselves to one particular Nordic country, but instead emphasise features that are common to the region as well as the topic's transnational character. In October 2006, for instance, a workshop entitled "Cultural Images in and of Africa” took place at The Nordic Africa Institute in Uppsala, gathering 25 researchers from the five Nordic countries with the aim of launching a discussion about the Nordic relation to colonialism (Palmberg 2006). Its organiser, Mai Palmberg, contributed to a book published three years later and entitled Complying with Colonialism: Gender, Race and Ethnicity in the Nordic Region. It was a cooperative effort between scholars located in Turku/Åbo (Keskinen et al. 2009). In the years that followed, several other anthologies appeared about different aspects of Nordic colonial complicity, including Whiteness and Postcolonialism in the Nordic Region: Exceptionalism, Migrant Others and National Identities, first published in 2012 (Loftsdóttir and Jensen eds. 2016), Scandinavian Colonialism and the Rise of Modernity: Small Time Agents in a Global Arena (concentrating on the early modern and modern periods) in 2013 (Naum and Nordin eds. 2013b), and Navigating Colonial Orders: Norwegian Entrepreneurship in Africa and Oceania in 2014 (Kjerland and Bertelsen eds. 2014). This last book is the result of a research project entitled "In the Wake of Colonialism: Norwegian Commercial Interests in Colonial Africa and Oceania" (WAKE), financed by the Norwegian Research Council (Kjerland 2015: xvii). Besides the book, the project resulted in several publications (e.g. Reiersen 2006; Bang 2008; Kjerland 2010; Kjerland and Rio eds. 2009), doctoral theses, and an exhibition. This project, concentrating on the Norwegian experience, shows that this emerging body of scholarship does not only examine the two dominant Scandinavian kingdoms, i.e. the ones that participated in the Berlin conference - Denmark and Sweden. Besides Norway, Finland was included 
in the above-mentioned Complying with Colonialism, as well as, for instance, in work by Timo Särkkä (Särkkä 2015); and Iceland appears in the work of Kristin Loftsdóttir and Gísli Pálsson (e.g. Loftsdóttir 2007; Loftsdóttir 2008; Loftsdóttir 2016; Loftsdóttir and Pálsson 2013).

This article presents a short overview of the ideas presented in this research. It concentrates on the Nordic colonial endeavour in the global South; questions of the Nordic presence in the Arctic (including the islands in the North Atlantic, Greenland, and Sápmi), are mostly left out - however, as the histories of Nordic expansion in the North and the South are inseparably entangled, it is not always possible to separate the two.

\section{The Nordic Region and the Colonial World: An Ambiguous Relation}

Research on the topic of Nordic colonialism acknowledges that the Nordic region's relation to the question of European colonial expansion is far from straightforward, for reasons that touch upon both the region's history and its own views on this history.

The first issue relates to the fact that the Nordic countries were themselves dependent on other powers and had a comparatively peripheral position in Europe. Only two countries - Sweden and Denmark - have an uninterrupted history of statehood. Norway did not gain full independence from its Swedish neighbour until 1905 (earlier, between 1397 and 1814, it had been under Danish domination); Finland remained under Russian rule until 1917; and Iceland acquired full independence from Denmark as late as 1944. The peripheral position of these countries could - and often did - work to their advantage, leaving them out or on the margins of the great upheavals of the twentieth century, such as the two world wars and the Cold War. It enabled the construction of a Nordic model of democracy and welfare, which rested in great part on the idea of being "the third way" between the Western and the Eastern blocks. At the same time, however, the region's peripherality made it more difficult to follow and take active part in intellectual and political trends at the heart of Europe (and in the West more generally), leading to aspirations of joining the political and intellectual centre.

The second issue concerns the national historical narratives of the Nordic countries. These narratives - which are more or less common for the whole region and are at the basis of their national identities - are stories of peaceful, hardworking, and impoverished peoples. During the time of the Cold War, this image was complemented by the idea of mediation and humanitarian effort in the so-called Third World. This narrative of the Nordic nations as "humanitarian powers" (see 
e.g. Anioł 2009: 134) presents them as innocent bystanders to European colonial expansion and even a kind of European conscience: by means of humanitarian aid and peace efforts, the Nordic countries could "right" the wrongs committed by the European empires (see e.g. Stråth 2002: 140). Furthermore, as Magdalena Naum and Jonas M. Nordin have pointed out in the introduction to the book Scandinavian Colonialism and the Rise of Modernity, from the national standpoint the history of the Nordic nations has been rewritten as disconnected from global economic and political trends and as contained within their modern-day national borders (Naum and Nordin 2013a: 4). Karen Fog Olwig, an anthropologist at the University of Copenhagen, refers to this process - in the Danish context - as "deglobalisation" (Olwig 2003). In the twentieth century, Danish national identity was "transformed from a multicultural, multi-ethnic seafarers' nation involved in the world's politics into the idea of an agrarian-based and mono-cultural society" (Naum and Nordin 2013a: 4). At the same time, the Nordic nations were also reinvented as ethnically homogenous, ignoring the presence not only of overseas colonial subjects, but also of indigenous peoples in the Nordic region itself, especially the Sámi.

The criticisms expressed by these researchers of Nordic colonialism about the erasure of the Nordic colonial past in national historical discourse can be divided into two interlinked strands: on the one hand, it draws attention to the expansion of the Nordic nations into extra-European spaces, and on the other, it emphasises the ideological and scientific complicity of the Nordic societies in colonial hierarchies.

\section{Colonial Presence}

In the most straightforward understanding, Nordic colonial presence relates to the fact that the Nordic countries - Denmark and Sweden (as well as, indirectly, Norway) - controlled overseas territories.

Between 1659 and 1850, Denmark-Norway (and later Denmark) controlled territories on Africa's Gold Coast (part of today's Ghana), from where it traded slaves, coffee, and gold. Denmark was also present in India - with trading stations in Tranquebar (Tharambambadi), Frederiksnagore (Sarampore), and the Fredrik Islands (Nicobar Islands), run by the Danish East India Company founded in 1616 - and the islands of Saint Thomas, Saint John, and Saint Croix in the Caribbean. However, most of these possessions were lost or sold before 1917. Swedish colonial possessions included - apart from a short-lived colony in Delaware, North America, and a fortress on the Gold Coast - the islands of Saint Barthélmy and Saint Martin in the Lesser Antilles, acquired from France in 1785 and returned in 1878. As Bjørn Bertelsen has commented, this issue has not yet been thoroughly researched (Bertelsen 2015: 11-12). 
However, as Naum and Nordin have pointed out, this understanding of colonialism is rather narrow, and for a comprehensive picture of the history of European expansion, colonial presence should be analysed in a wider, somewhat less straightforward sense. One way to do this is to include the participation in global trade networks, including the transatlantic triangular slave trade, in any understanding of colonialism and colonial presence (Naum and Nordin 2013a: 4). The appearance of the Dane Fresleven (as well as several Swedes) in Conrad's Heart of Darkness, as seen in the opening quote, is not surprising when you realise that the colonial presence of Scandinavians in extra-European spaces, such as Africa, Oceania, and other territories, often took the form of their activities as sailors, traders, investors, entrepreneurs, researchers, and missionaries, as also discussed by Mai Palmberg (Palmberg 2009: 40-41). In this capacity, they influenced and profited from global European supremacy by way of trade and navigation, settlement in European colonies, and the gathering of ethnographica, among others. The book Navigating Colonial Orders, as well as the larger project WAKE, is a good example of this approach. As Kirsten Alsaker Kjerland has argued, despite Norway's traditional national "narrative of historical poverty", one should not forget that the country wielded considerable economic power in the form of its merchant fleet, the third-largest in the world at the time of high colonialism (i.e. from the second half of the nineteenth until the first decades of the twentieth century) (Kjerland 2015: $\mathrm{xV}$-xvi). The fact that most of this fleet operated away from Norwegian ports emphasises the important role it played in connecting and maintaining the European colonial order. Furthermore, Svein Ivar Angell has brought attention to the fact that the Norwegian merchant fleet was a significant factor in the break-up of the union between Norway and Sweden in 1905 (Angell 2015).

The fact that the Nordic countries were active in overseas territories belonging to the global trade networks is also emphasised in the other research projects mentioned above. To quote just some examples, Chris Evans and Göran Rydén analysed the Swedish export of iron in the early modern transatlantic trade (Evans and Rydén 2013), and Timo Särkkä looked at individual cases of Finns in Rhodesia (Särkkä 2015). In this context, the Finnish case is problematic because, as mentioned, until 1917 the country itself was under the rule of another empire - Russia - and striving to ascertain its own national identity. Therefore, Särkkä argues that "certain beliefs and perceptions" displayed by Finns in colonial situations were typical of their nationality, i.e. an identity that had developed in relation to the domination of a foreign empire, and as such differed from the identity represented by the nationals of colonial powers such as Great Britain (Ibid.: 98). In regard to colonialism, Särkkä believes that concentrating on smaller and less studied countries and nations can be instructive, because in this way "we can discover new sources, written in languages that have as yet rarely been heard in accounts of the colonial experience" (Ibid.: 78). 


\section{Colonial Complicity}

One of the questions Särkkä asks is whether nations that do not possess colonial empires - "noncolonial colonials", to use Bertelsen's phrase (Bertelsen 2015) - can be considered imperialists. "A closer examination", he concludes, "reveals that even European countries that never had overseas colonies, such as Finland, were involved in the colonial world: Finns were sent out as colonisers and produced images of colonial 'others'” (Särkkä 2015: 98). In this sense, participation in the colonial project is connected to the production and dissemination of knowledge that has perpetuated global hierarchies.

The European colonial endeavour was not only built on political, military, and economic power, but it was also supported by discursive practices and European science. As such, colonialism can be considered a system of (production of) knowledge, as argued for instance by Edward Said (Said 2014: 31ff; Said 2007). The time of high colonialism coincided with the time of the development of science, including anthropology and geography, which were used in describing and conceptualising the world in a way that created the hierarchies underlying the colonial system. By ordering the world in the name of science, European botanists, geographers, and ethnographers ascribed this world with hierarchies and centre-periphery relations. This also included travel literature, which is - as argued by Mary Louise Pratt rarely an "innocent" description of the authors' experiences or an expression of their interest in the world. It is also a hierarchy-making tool, establishing and maintaining the colonial order, conceptualising the extra-European world as something to describe, measure, and infuse with meaning - but a world that cannot or should not produce meaning itself. Travel reports thus "encode and legitimate the aspirations of economic expansion and empire" (Pratt 1995: 5, 15-37).

In light of this, taking an active part in the development of science - for example by contributing to research carried out in the global South - ensured both scientists and the nations they represented that they received a place in these hierarchies, at the same time as they reinforced them. Contributions to science should thus be seen in the context of the political and economic aspirations of states striving to position themselves as strong, Western, and European - and the production of knowledge as a tool in realising both these aspirations and the nationalist articulations of the countries involved, especially countries on the European periphery, such the Nordic region. Joining the European discourse, therefore, could be interpreted as an attempt to also join the European core as the producer of discourse, and thus of moving away from the periphery. For these reasons, countries that never possessed colonies are not immune to what Palmberg calls the "colonial mind": they share the European discourse about the hierarchies of peoples and the systemic racism that is present in European science and culture, in other words, 
they partake in a "shared European cultural outlook" (Palmberg 2009: 47). On the Internet site of the research project Colonial Mind, Palmberg writes:

The Nordic countries did not take part in the nineteenth-century scramble for Africa, but it seems as if all Nordic countries shared in the colonialist [E] urocentric ideas of hierarchical pattern of development, and a concomitant hierarchical evolution of "races". [...] The Nordic countries identified with the colonial project and in the inter-war years were at the forefront of eugenics, or (translated from Swedish) "race biology", at the same time as the welfare state was built, with its emphasis on equality (Palmberg 2006).

This approach attempts to tie questions of the "colonial mind" and the reproduction of colonial discourses to the Nordic welfare state, not as a marginal occurrence, but as an integral part of its history. In her contribution to Complying with Colonialism: Gender, Race and Ethnicity in the Nordic Region, Palmberg argues that many countries that joined the race for extra-European territories comparatively late and that never succeeded in acquiring colonies sensu stricto, have not devoted enough attention to their own place in the global system of European domination and their relationship to overseas territories under more or less direct European rule. Such a lack of reflection on one's own complicity in the colonial project can lead to a lack of sensitivity to the colonial and postcolonial experience, as well as to one's own position - as white Europeans - in the system of hierarchies and power that was constructed to support the global European dominance: "We are less prepared than we need to be for the prejudices encountered by immigrants of colour, and even less so for the incidents of racist crimes. Racism is simply seen as bad and extremely impolite behaviour towards foreign guests, but not as part of an inherited ideology" (Palmberg 2009: 36-37).

Complying with Colonialism, as the title indicates, examines the concepts of race, ethnicity, and gender in the Nordic region that are the result of this inherited ideology. The point of departure of the book is the notion of "complicity" as developed by Ulla Vuorela, an anthropologist at the University of Tampere, which in turn is based on the concept of "complicity" used by Gayatri Spivak (Spivak 1999). In Vuorela's formulation, complicity is

participation in the hegemonic discourses, involvement in the promotion of universal thinking and practices of domination. Complicity is an important notion for those of us who are not quite situated in the centre; always wanting to get closer; our responses to the invitation give us a complicit position that we rarely even recognise. It also resembles a "tacit" acceptance of hegemonic discourses, since if we want to be accepted by the centres it is only possible, or so we think, on their terms (Vuorela 2009: 20).

One example of a "response to the invitation" is Finnish scholars - more precisely Edvard Westermarck, who became a professor at the University of London - join- 
ing the European anthropological discourse, with the centre in the capital of the British Empire and its institutions of research and education. Kristin Loftsdóttir adds Icelandic examples. When analysing depictions of Africa in the Icelandic journal Skirnir, she interprets them as part of a more general European narrative about non-whites - Palmberg's "colonial mind". These depictions also serve to safely situate Icelanders in relation to other peoples in and beyond Europe: despite Iceland's lack of independence, care was taken to distance the country from other dependent peoples in the Danish Kingdom, such as Greenlanders, as well as from Africans (Loftsdóttir 2008: 183). Loftsdóttir also points out the gendered aspect of the narrative on both the European and the Icelandic level (referring to Pratt's idea of "brotherhood" (Pratt 1990)). It concentrates on European men - travellers and scientists - as disciplined, courageous, and rational bringers of civilisation and progress to Africa, and the narrative's reproduction in Iceland allowed educated Icelandic men to imagine themselves on equal footing with educated men in Europe. "By repeating European stereotypes of Africa", Loftsdóttir comments, "educated Icelandic males associated themselves with Europe in contrast with those that they saw as savages" (Loftsdóttir 2007: 27; See also: Loftsdóttir 2008: 184).

The interesting merging of Africans and Greenlanders in the narratives analysed by Kristin Loftsdóttir shows another aspect of the Nordic colonial involvement: the fact that it was also directed at and towards the north. This included both the territorial expansion in the Arctic (the northernmost parts of the European mainland and the North Atlantic islands, including Greenland), and the construction of racial discourses. These racial discourses were directed against the Sámi on the Scandinavian Peninsula and against Greenlanders, in an attempt at "internal colonisation" and constructing these people as orientalised others, taking away their agency (Bravo and Sörlin 2002: 4-5). Although this northbound colonialism has also increasingly been studied inside the Nordic region, including its dimension as an integral part of the construction of welfare states, it is not the focus of this article. However, it is interesting to note that Icelanders, themselves an object of Danish imperialism, attempted to gain acceptance as part of the centre by perpetuating its discourses, thus becoming complicit in the Danish colonial project.

\section{Conclusions}

Conrad only needed a handful of carefully crafted sentences to portray the character of Fresleven the Dane, as quoted at the beginning of this article: a gentle, quiet person, who nevertheless relied on violence in "asserting his self-respect" towards the Africans. In a way, this description is an apt illustration of the colonial endeavour of the Nordic countries and people in general: despite their (self-)image 
as peaceful and humanitarian Europeans, they have not been innocent or devoid of exploitation and violence in their encounter with non-Europeans. At the same time, their complicity in the European colonial project has often taken the form of asserting their own self-respect - i.e. their place in the global hierarchies, relating both to the European centre and the extra-European world - through the perpetuation of racial discourses.

For these reasons, the emerging field of colonial studies in the Nordic region is especially important, which not only has the cognitive function of filling in the blank spaces in the national narratives and the narratives of European colonialism, but it also questions the region's "assumed outsider status" (Vuorela 2009: 29), and explores - and admits - the extent of its complicity and responsibility. In this sense, this research sets an example for other "non-colonial colonials", including Poland, whose colonial complicity has not yet been sufficiently studied and confronted.

\section{Literature}

Angell, S.I. (2015). The Consular Affairs Issue and Colonialism. In: K.A. Kjerland and B.E. Bertelsen (eds.). Navigating Colonial Orders: Norwegian Entrepreneurship in Africa and Oceania. New York: Berghahn, pp. 153-172.

Anioł, W. (2009). Mocarstwo humanitarne? Norwegia wobec nowych wyzwań społecznych. Problemy Polityki Społecznej: studia i dyskusje 12: 121-144.

Bang, A.K. (2008). Zanzibar-Olsen: norsk trelasthandel i Øst-Afrika, 1895-1925. Bergen: Fagbokforlag.

Bertelsen, B.E. (2015). Introduction. Norwegians navigating colonial orders in Africa and Oceania. In: K.A. Kjerland and B.E. Bertelsen (eds.). Navigating Colonial Orders: Norwegian Entrepreneurship in Africa and Oceania. New York: Berghahn, pp. 1-37.

Bravo, M. and S. Sörlin. (2002). Narrative and Practice - an Introduction. In: M. Bravo and S. Sörlin (eds.). Narrating the Arctic: A Cultural History of Nordic Scientific Practices. Canton, MA: Science History Publications, pp. 3-32.

Conrad, J. (2010). Heart of Darkness. Firenze-Milano: Giunti Editore.

Evans, Ch. and G. Rydén. (2013). From Gammelbo Bruk to Calabar: Swedish Iron in an Expanding Atlantic Economy. In: M. Naum and J.M. Nordin (eds.). Scandinavian Colonialism and the Rise of Modernity: Small Time Agents in a Global Arena. New York: Springer Science \& Business Media, pp. 53-68.

Keskinen, S., S. Tuori, S. Irni and D. Mulinari (eds.). (2009). Complying with Colonialism: Gender, Race and Ethnicity in the Nordic Region. London-New York: Routledge.

Kjerland, K.A. (2010). Nordmenn i det koloniale Kenya. Oslo: Scandinavian Academic Press.

Kjerland, K.A. (2015). Preface. In: K.A. Kjerland and B.E. Bertelsen (eds.). Navigating Colonial Orders: Norwegian Entrepreneurship in Africa and Oceania. New York: Berghahn, pp. xiv-xviii.

Kjerland, K.A. and B.E. Bertelsen (eds.). (2014). Navigating Colonial Orders: Norwegian Entrepreneurship in Africa and Oceania. New York: Berghahn.

Kjerland, K.A. and K.M. Rio (eds.). (2009). Kolonitid: nordmenn på eventyr og big business i Afrika og Stillehavet. Oslo: Scandinavian Academic Press. 
Loftsdóttir, K. (2007). "Pure Manliness": The Colonial Project and Africa's Image in the $19^{\text {th }}$ Century Iceland. Conference paper. Uppsala: Nordic Africa Days.

Loftsdóttir, K. (2008). Shades of Otherness: Representations of Africa in $19^{\text {th }}$-Century Iceland. Social Anthropology 16 (2): 172-186.

Loftsdóttir, K. (2016). Belonging and the Icelandic Others: Situating Icelandic Identity in a Postcolonial Context. In: K. Loftsdóttir and L. Jensen (eds.). Whiteness and Postcolonialism in the Nordic Region: Exceptionalism, Migrant Others and National Identities. London-New York: Routledge, pp. 57-72.

Loftsdóttir, K. and L. Jensen (eds.). (2016). Whiteness and Postcolonialism in the Nordic Region: Exceptionalism, Migrant Others and National Identities. London-New York: Routledge.

Loftsdóttir, K. and G. Pálsson (2013). Black on White: Danish Colonialism, Iceland and the Caribbean. In: M. Naum and J.M. Nordin (eds.). Scandinavian Colonialism and the Rise of Modernity: Small Time Agents in a Global Arena. Springer Science \& Business Media, pp. 37-52.

Mommsen, W.J. (1988). Preface. In: S. Förster, W.J. Mommsen and R. Robinson (eds.). Bismarck, Europe and Africa: The Berlin Africa Conference 1884-1885 and the Onset of Partition. Oxford: Oxford University Press [for] German Historical Institute, pp. v-xi.

Naum, M. and J.M. Nordin. (2013a). Introduction: Situating Scandinavian Colonialism. In: M. Naum and J.M. Nordin (eds.). Scandinavian Colonialism and the Rise of Modernity: Small Time Agents in a Global Arena. New York: Springer Science \& Business Media, pp. 3-16.

Naum, M. and J.M. Nordin (eds.). (2013b). Scandinavian Colonialism and the Rise of Modernity: Small Time Agents in a Global Arena. New York: Springer Science \& Business Media.

Olwig, K.F. (2003). Narrating deglobalization: Danish perceptions of a lost empire. Global Networks 3 (3): 207-222.

Palmberg, M. (2006). The Nordic Colonial Mind. The Nordic Africa Institute, http://nai.uu.se/ research/finalized_projects/cultural_images_in_and_of/colonial_mind/index.xml (accessed: 20 April 2017).

Palmberg, M. (2009). The Nordic Colonial Mind. In: S. Keskinen, S. Tuori, S. Irni and D. Mulinari (eds.). Complying with Colonialism: Gender, Race and Ethnicity in the Nordic Region. London-New York: Routledge, pp. 35-50.

Pratt, M.L. (1990). Women, Literature and National Brotherhood. In: E. Bergmann, J. Greenberg, G. Kirkpatrick, F. Masiello, F. Miller, M. Morello-Frosch, K. Newman and M.L. Pratt. Women, Culture, and Politics in Latin America. Berkeley: University of California Press, pp. $48-73$.

Pratt, M.L. (1995). Imperial Eyes: Travel Writing and Transculturation. London-New York: Routledge.

Reiersen, E. (2006). Fenomenet Thams. Oslo: Aschehoug.

Said, E.W. (2007). Culture and Imperialism. London: Vintage.

Said, E.W. (2014). Orientalism. New York: Knopf Doubleday Publishing Group.

Särkkä, T. (2015). Imperialists without an empire? Journal of Migration History 1 (1): 75-99.

Spivak, G.Ch. (1999). A Critique of Postcolonial Reason: Toward a History of the Vanishing Present. Cambridge, MA: Harvard University Press.

Stråth, B. (2002). The Swedish Demarcation from Europe. In: M. af Malmborg and B. Stråth (eds.). The Meaning of Europe: Variety and Contention within and among Nations. OxfordNew York: Berg, pp. 125-147.

Vuorela, U. (2009). Colonial Complicity: The "Postcolonial" in a Nordic Context. In: S. Keskinen, S. Tuori, S. Irni and D. Mulinari (eds.). Complying with Colonialism: Gender, Race and Ethnicity in the Nordic Region. London-New York: Routledge pp. 19-33. 